\title{
Chagas Disease: from Bush to Huts and Houses. Is it the Case of the Brazilian Amazon?
}

\author{
José Rodrigues Coura/ ${ }^{+}$, Angela Cristina Verissimo Junqueira, \\ Marcio Neves Boia/*, Octavio Fernandes/**
}

\begin{abstract}
Departamento de Medicina Tropical, Instituto Oswaldo Cruz, Av. Brasil 4365, 21045-900 Rio de Janeiro, RJ,
Brasil *Disciplina de Doenças Infecciosas e Parasitárias, Departamento de Clínica Médica **Disciplina de Parasitologia, Departamento de Patologia e Laboratórios, Faculdade de Ciências Médicas, Uerj,

Rio de Janeiro, RJ, Brasil
\end{abstract}

Two of the major problems facing the Amazon - human migration from the other areas and uncontrolled deforestation - constitute the greatest risk for the establishment of endemic Chagas disease in this part of Brazil.

At least 18 species of triatomines had been found in the Brazilian Amazon, 10 of them infected with Trypanosoma cruzi, associated with numerous wild reservoirs. With wide-range deforestation, wild animals will perforce be driven into other areas, with tendency for triatomines to become adapted to alternative food sources in peri and intradomicilies.

Serological surveys and cross-sectional studies for Chagas disease, carried out in rural areas of the Rio Negro, in the Brazilian Amazon, showed a high level of seropositivity for T. cruzi antibodies. A strong correlation of seroreactivity with the contact of gatherers of piaçava fibers with wild triatomines could be evidenced.

Key words: Trypanosoma cruzi - Chagas disease - seroprevalence - Brazilian Amazon

Chagas disease in the Brazilian Amazon has always been considered to be a sylvatic enzooty. Since 1924, when Carlos Chagas confirmed as Trypanosoma cruzi trypanosomes found by AbenAthar in Saimiri sciureus monkeys from the State of Pará, several species of sylvatic animals - marsupials, chiroptera, rodents, edentates and primates - have been identified as T. cruzi reservoirs in the Amazon region (Barretto1964, Deane 1964).

At least 18 species of triatomine have been found in the region (Table I), 10 of them infected with T. cruzi or "cruzi-like" trypanosomes (Lent \& Wigodzinsky 1979, Miles et al. 1981, 1983, Brazil et al. 1985, Barrett \& Guerreiro 1991). Although there are no descriptions of domestic triatomines in the Brazilian Amazon it can not be definitively concluded from this that Chagas disease is not endemic in the Amazon, given the small number of existing studies, the vast scale of the

\footnotetext{
This work was supported by Conselho Nacional de Desenvolvimento Científico e Tecnológico (CNPq) and Fundação Nacional de Saúde (FNS).

${ }^{+}$Corresponding author. Fax: +55-21-280.3740

E-mail: coura@gene.dbbm.fiocruz.br

Received 9 June 1999

Accepted 9 August 1999
}

region and the wide variety of intraregional differences.

The risk of endemic Chagas disease in the Brazilian Amazon were stressed in reviews (Coura 1990, Coura et al. 1993, 1994b, Valente \& Valente 1993), with 38 human cases described up to 1992. The national serological survey carried out by the Ministry of Health in Brazil from 1975 to 1980 (Camargo et al. 1984) showed a $1.88 \%$ seroprevalence for Chagas infection in the human population of the State of Amazonas, although at the time this result was considered to be due to a possible cross-reaction or "false-positive" phenomenon.

Given the aforementioned findings, together with the evidence of human positive serology for Chagas infection (Ferraroni et al. 1977) and the occurrence of one acute case in a patient from the district of Barcelos (Souza-Lima et al. 1985) in the northern part of the State of Amazonas, we decided to carry out a multidisciplinary study in this area. Following our short review on the subject of Chagas disease in the Brazilian Amazon (Coura et al. 1994b), we herein present results of several studies.

\section{MATERIALS AND METHODS}

Location of the study area - The administrative district of Barcelos is located in the northern part of the State of Amazon, bordering in the east with the State of Roraima, in southeast and south with 
TABLE I

Species of Triatominae found in the Brazilain Amazon

Belminus herreri

Cavernicula lenti

Cavernicula pilosa

Eratyrus mucronatus ${ }^{a}$

Microtriatoma trinidadensis a

Panstrongylus geniculatus ${ }^{a}$

Panstrongylus lignarius ${ }^{a}$

Panstrongylus rufotuberculatus ${ }^{a}$ Triatoma rubrofasciata
Rhodnius brethesi ${ }^{a}$
Triatoma rubrovaria

$a$ : found infected with Trypanosoma cruzi or "cruzi-like"

the administrative districts of Novo Airão and Maraã, in the west with the administrative district of Santa Isabel do Rio Negro and in north with Venezuela (latitude $0^{\circ} 58^{\prime} 1^{\prime}$ " south of the equator and longitude $62^{\circ} 56^{\prime}$ west of Greenwich). The town of Barcelos, where this study was carried out, is located on the right bank of the Rio Negro, 490 $\mathrm{km}$ up-river from Manaus, the capital of the State of Amazon (Fig. 1).

Surveys and samples - Three serological surveys for Chagas infection were carried out, respectively in 1991, 1993 and 1997 using conglomerate family samples from families residing in the town of Barcelos, employing indirect immunofluorescent tests for anti- $T$. cruzi antibodies. In the first survey (1991) 628 blood samples from the residents of 142 dwellings (one dwelling in every five) were tested.

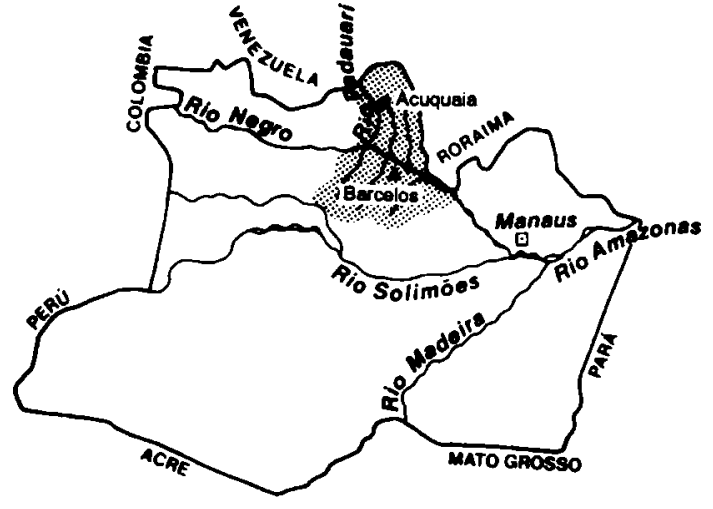

Fig. 1: location of Barcelos in the State of Amazon, Brazil.

In 1993 another 658 samples from the residents of 171 dwellings (one dwelling in every four) were examined. More recently, other 886 samples from 194 dwellings were analyzed (Fig. 2).

Laboratory procedures - The blood samples were centrifuged and sera stored at $-20^{\circ}$ until use. The sera were examined using indirect immunofluorescence technique of Fife and Muschel (1959) as modified by Camargo (1966) and Petana and Willcox (1975). The sera were serially diluted from 1:40 to $1: 320$ in PBS at $\mathrm{pH} 7.2$.

The tests were carried out employing human anti-gammaglobulin type IgG (Biolab), at a dilution 1:100. Formolized culture forms of T. cruzi Y strain were used as antigen. The reaction was ob-

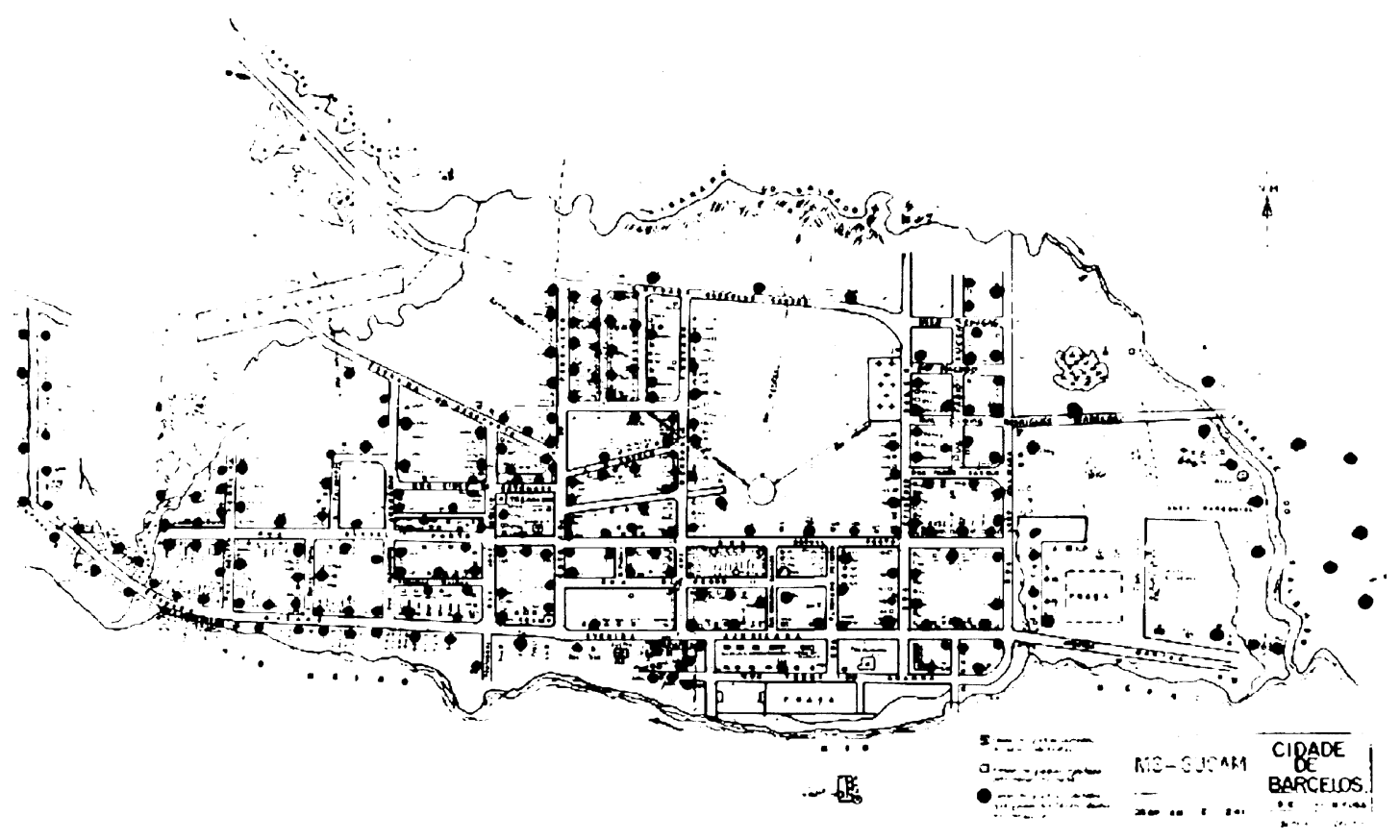

Fig. 2: distribution of the dwellings investigated. Barcelos, Brazilian Amazon. 
served through a Leitz microscope (Dialux model) with epi-illumination for immunofluorescence. The positive reactions were confirmed by enzymelinked immune absorbent assay (ELISA). In the last survey (1997), a screening test for T. cruzi based on agglutination reactions of coloured polymer particles (ID-PAGIA ${ }^{\mathrm{TM}}$, DIAMED), sensitized by three distinct $T$. cruzi peptides was used. The reactions were confirmed by indirect immunofluorescence, conventional and recombinant ELISA (CRA \& FRA).

Interviews, clinical and electrocardiographic exams - In the surveys, two questionnaires were used, one residential, to evaluate the social, economic and sanitary conditions and another individual for anamnesis and clinical examinations.

The individuals with positive serology for $T$. cruzi antibodies were interviewed and submitted to clinical and electrocardiographic examination with the 12 classical standard leads (bipolar $\mathrm{D}_{1}$, $\mathrm{D}_{2}$ and $\mathrm{D}_{3}$, unipolar aVR, aVL and aVF and precordial $\mathrm{V}_{1}$ to $\mathrm{V}_{6}$ ). During the interviews we showed a collection of Triatoma, Panstrongylus and Rhodnius to see if the patients could recognized them.

Xenodiagnosis - All of the patients with positive serology for anti-T. cruzi antibodies, who gave the consent were submitted to xenodiagnosis with 40 4th stage nymphs, 20 of $T$. infestans and 20 of P. megistus (fasting for at least 20 days). The nymphs were distributed in four wooden boxes with ten nymphs each. Two boxes were applied to each inner forearm of the patients and left to feed for $30 \mathrm{~min}$. The nymphs were again fed with chicken blood 23 days later and checked 45 days after being applied on the patients.

Feces from a pool of two or three nymphs were collected using slight abdominal pressure and deposited on slides containing one drop of PBS at $\mathrm{pH} 7.2$, homogenized, covered with a 22x22 mm film and examined under a microscope which magnified their diameter 400 fold; if this was negative, the entire intestinal content was dissected, homogenized and examined using the same technique. Before checking for $T$. cruzi the hemolymph and the salivary glands of all nymphs were checked for $T$. rangeli.

Other tests - Polymerase chain reaction (PCR) amplification of the variable region of the minicircle molecule, one component of the mitochondrial genome (kDNA) of T. cruzi was performed as previously described in 30 patients that showed to be seropositive in the first survey (Britto et al. 1995). Molecular typing of two distinct $T$. cruzi strains isolated by xenodiagnosis was carried out by analyzing the intergenic transcribed spacer of the mini-exon gene (Fernandes et al. 1998a,b).

\section{RESULTS}

In the first serological survey (1991), of 710 sera tested by the indirect immunofluorescence for anti-T. cruzi antibodies, 89 (12.5\%) were positive. In the second survey (1993), of 658 samples examined by the same technique $90(13.7 \%)$ were also positive. Finaly in the third survey (1997), of 886 sera analyzed by the agglutination test, 117 $(13.2 \%)$ were reactive, thus confirming the results obatined in the previous surveys. Table II shows the distribution of the patients by age group and the results of serology.

When we showed a collection of Triatoma, Panstrongylus and Rhodnius during the interview $206(20.7 \%)$ of the patients recognized the triatomines which they call "piaçavas' lice", 139 $(67.5 \%)$ knew the bugs from their work places being gatherers of piaçava fibers in rural areas and $62(30 \%)$ said that they have been bitten by the bugs in their huts in rural areas (the information from children younger then 10 , was gathered from

TABLE II

Seroprevalence of chagasic infection in Barcelos, distributed by age in 1991, 1993 and 1997

\begin{tabular}{|c|c|c|c|c|c|c|}
\hline \multirow[t]{3}{*}{ Age (years) } & \multicolumn{6}{|c|}{ Seroprevalence } \\
\hline & \multicolumn{2}{|c|}{1991} & \multicolumn{2}{|c|}{1993} & \multicolumn{2}{|c|}{1997} \\
\hline & $\begin{array}{c}\text { Tested } \\
\mathrm{N}\end{array}$ & $\begin{array}{c}\text { Positive } \\
(\%)\end{array}$ & $\begin{array}{c}\text { Tested } \\
\mathrm{N}\end{array}$ & $\begin{array}{c}\text { Positive } \\
(\%)\end{array}$ & $\begin{array}{c}\text { Tested } \\
\mathrm{N}\end{array}$ & $\begin{array}{c}\text { Positive } \\
(\%)\end{array}$ \\
\hline $0-10$ & 197 & 7.6 & 248 & 5.6 & 215 & 12.1 \\
\hline $11-20$ & 208 & 11.7 & 143 & 13.3 & 255 & 25.4 \\
\hline $21-30$ & 91 & 14.3 & 91 & 9.9 & 139 & 15.7 \\
\hline $31-40$ & 76 & 19.7 & 58 & 8.6 & 100 & 11.3 \\
\hline $41-50$ & 58 & 12.1 & 42 & 7.1 & 69 & 7.8 \\
\hline $51-60$ & 34 & 8.8 & 34 & 11.8 & 43 & 4.9 \\
\hline$>60$ & 46 & 22.2 & 42 & 24.0 & 65 & 7.4 \\
\hline Total & 710 & 12.5 & 658 & 13.7 & 886 & 13.2 \\
\hline
\end{tabular}


their parents). Considering the group that described a previous attack of the triatomine, $25.8 \%$ were seropositive for $T$. cruzi antibodies against $11.7 \%$ of the non bitten people $(\mathrm{p}=0.03)$.

The electrocardiograms showed alteration in 9 (8\%) of the 112 patients. Four had ventricular extrasystoles: isolated, frequent or bigeminal. One patient showed supraventricular extrasystoles, first degree atrioventricular block and intraventricular delayed stimulus conduction. Two patients presented right bundle-branch block, one of them of the first degree and the other of the 3rd degree, associated with the left anterior hemiblock which is very suggestive of Chagas disease.

From 156 xenodiagnosis performed on patients with seroreactive for $T$. cruzi antibodies, only 3 $(1.9 \%)$ were positive for the protozoa. The exams of the hemolymph and salivary glands were negative for $T$. rangeli in all bugs used in the xenodiagnostic assays.

PCR of kDNA performed up to now on the blood of 30 seroreactive patients, was positive for T. cruzi in $3(10 \%)$ of the cases.

Of the three $T$. cruzi isolates obatined after the xenodiagnostic procedure, one strain was difficult to adapt in mice and was lost during cultivation. They all show a very long pre-patent period and do not kill mice; furthermore strains grow very slowly in culture media. The two remaining isolates were submitted to the mini-exon gene typing assay, which revealed that they belong to the lineage of $T$. cruzi that is usually found in the sylvatic environment. Interestingly, one isolated presented an insertion in the mini-exon gene non-transcribed spacer that is a molecular marker for zimodeme III (Miles et al. 1980, Fernandes et al. 1998b).

\section{DISCUSSION}

The high level of seropositivity for anti-T. cruzi antibodies found in this study does not necessarily signify that all the cases with positive serology are actually infected with $T$. cruzi. Nonetheless, the study shows strong epidemiological and serological correlations, such as previous contact of the positive cases with wild triatomines, isolation of T. cruzi by xenodiagnosis and positivity of PCR of kDNA of T. cruzi in some cases. This data strongly suggest that significant proportions of the serological positive cases will be confirmed to be infected with $T$. cruzi.

A large proportion of the seropositive individuals for anti-T. cruzi antibodies recognized the triatomines shown as "piaçavas' lice", $20.7 \%$ knew the bugs from their work places, being gatherers of piaçava fibers in rural areas and $30 \%$ of those said that they have been bitten by the bugs in their huts. On the other hand none of those interviewed recognized the existence of the bugs in their houses in the town of Barcelos, but only in rural areas where the piaçava fiber (Leopoldinia piassava) is collected (Fig. 3). All the piaçavas gatherers and their families with positive serology for anti-T. cruzi antibodies recognized the triatomines and a great number of them mentioned that they have been bitten by these bugs, which show a link between $T$. cruzi infection and one's profession.

Studies done by Matta $(1919,1922)$ and more recently by Mascarenhas (1991) and by our group (Coura et al. 1993, 1995), have shown the contact the piaçava gatherers had with Rhodnius brethesi in the region of Rio Negro, State of Amazonas, where we described an attack on the human populations by this bug (Coura et al. 1994a).

Cross-serological reaction with antibodies from cutaneous leishmaniasis, leprosy, tuberculosis and T. rangeli could be a possibility in some cases. In the present study we found only four cases of cutaneous leishmaniasis, two cases of leprosy and two of tuberculosis and we have not found by xenodiagnosis any case of $T$. rangeli infection. However the contact of the population with triatomines of the genus Rhodnius gives rise to great risk of transmission of that parasite, as we have shown (Coura et al. 1996), by diagnosing three human cases in 86 hemocultures in the Brazilian Amazon.

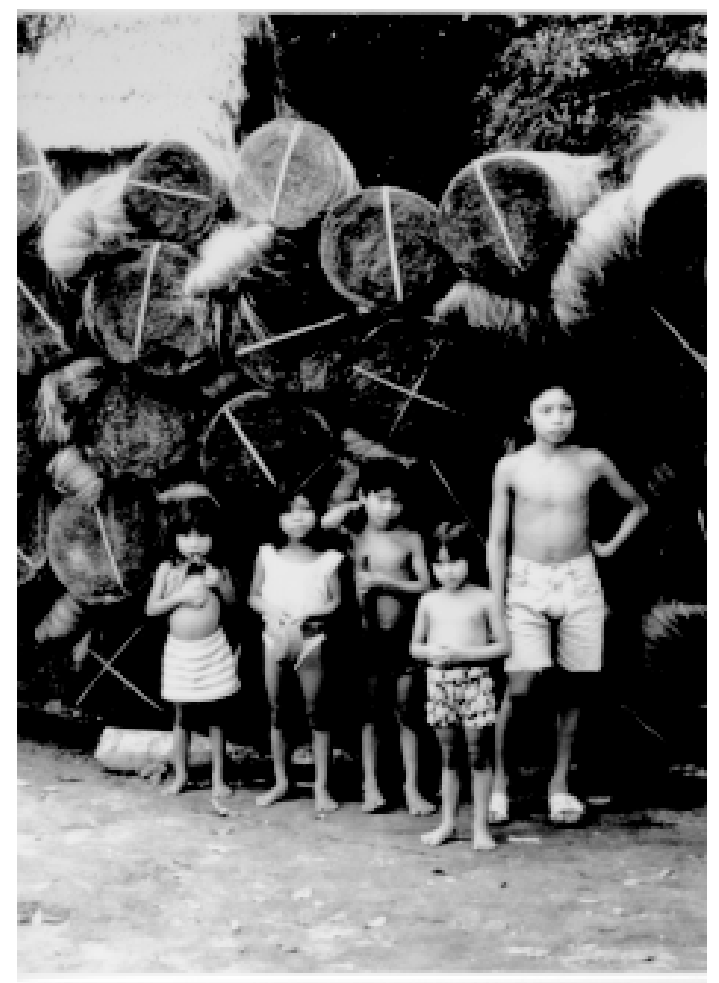

Fig. 3: piaçavas fibers collected and stored for transportation. 
Electrocardiograms of 112 seropositive patients for anti-T. cruzi antibodies showed nine (8\%) alterations, four of them suggestive of chagasic miocardiopathy. However, all the patients with electrocardiographic alterations were over 60 years of age which makes it difficult to exclude an association with atheroesclerosis.

Uncontrolled deforestation and colonization in the Amazon are currently amongst the great concerns of (thinking) citizens in our country, and give rise to great international speculation regarding the possibility of exponential increase in these activities (Fearnside 1982) . Several studies on the matter have been carried out recently and will not be discussed here due to lack of space. With wideranging deforestation, wild animals will perforce be driven into other areas, with a tendency for triatominae to become adapted to alternative food sources in peri and intra-domiciliary areas. Barretto (1967), in his study of T. cruzi reservoir hosts and vectors, gives a painstaking analysis of the consequences of modifying natural foci. Forattini (1980) and Aragão (1983) have carried out datailed studies of the origin of and preadaptation to domiciliary activity of triatomines in Brazil, corroborating with our assertion.

Finally, uncontrolled migratory movements from the south, southeast, northeast and west-central areas towards the Amazon, increased during recent years, have been responsible for maintaining and exacerbating various endemic parasitic diseases in Brazil, such as malaria. In the case of Chagas disease, although its adaptation mechanisms are slower, it poses one the most serious threats of transposition of an endemic disease into the Amazon; the effects of this will become evident during the next century unless the following precautions are taken: (a) reduction and control of deforestation, particularly on the periphery of population centres; (b) constant surveillance of domestic adaptation of wild triatominae and transposition of triatominae and domestic reservoir hosts from endemic areas to the Amazon; (c) formulation of a global policy for the settlement and colonization of the Amazon, which would simultaneously preserve the ecology of the area, while promoting its socioeconomic development.

\section{REFERENCES}

Aragão MB 1983. Domiciliação de triatomíneos ou préadaptação à antropofilia e a ornitofilia(?). Rev Saúde Publ S Paulo 17: 51-57.

Barrett TV, Guerreiro JCH 1991. Os triatomíneos (Hemiptera, Reduviidae) em relação à doença de Chagas na Amazônia, p.119-130. In AL Val, R Figliuolo \& E Feldberg (eds), Bases Científicas para Estratégia de Preservação e Desenvolvimento da Amazônia: Fatos e Perspectivas, Instituto Nacional de Pesquisas da Amazônia, Manaus.

Barretto MP 1964. Reservatórios do Trypanosoma cruzi nas Américas. Rev Bras Malar 16: 527.

Barretto MP 1967. Estudo sobre reservatórios e vetores do Trypanosoma cruzi. XXII. Modificações de focos naturais de tripanosomíase americana e suas consequências. Rev Soc Bras Med Trop 1: 167-173.

Brazil RP, Silva AR, Albarelli A, Valle JF 1985. Distribuição e infecção de triatomíneos por Trypanosoma cruzi na Ilha de São Luiz, Maranhão. Rev Soc Bras Med Trop 18: 257-260.

Britto C, Cardoso A, Ravel C, Santoro A, Pereira JB, Coura JR, Morel CM, Wincker P 1995. Trypanosoma cruzi: parasite detection and strain discrimination in chronic chagasic patients from northeastern Brazil using PCR amplification of kinetoplast DNA and nonradioactive hybridization. Exp Parasitol 81: 462-471.

Camargo ME 1966. Fluorescent antibody test for serodiagnosis of American trypanosomiasis. Technical modification employing preserved forms of Trypanosoma cruzi in a slide test. Rev Inst Med Trop $S$ Paulo 8: 227-234.

Camargo ME, Silva GR, Castilho EA, Silveira AC 1984. Inquérito sorológico da prevalência da infecção chagásica no Brasil, 1975-1980. Rev Inst Med Trop $S$ Paulo 26: 192-204.

Chagas C 1924. Infection naturelle des singes du Pará (Crysotrix sciureus) par Trypanosoma cruzi. C R Soc Biol (Paris) 90: 873.

Coura JR 1990. The risk of endemic Chagas disease in the Brazilian Amazon. Rev Soc Bras Med Trop 23: 67-70.

Coura JR, Arboleda MN, Willcox HPF 1993. Doença de Chagas na Amazônia brasileira. Rev Soc Bras Med Trop 26 (Suppl. 2): 15-17.

Coura JR, Arboleda MN, Willcox HPF 1995. Chagas disease in the Brazilian Amazon. II - A serological survey. Rev Inst Med Trop São Paulo 37: 103-107.

Coura JR, Barrett TV, Arboleda MN 1994a. Ataque de populações humanas por triatomíneos silvestres no Amazonas: uma nova forma de transmissão da infecção chagásica? Rev Soc Bras Med Trop 27: 251253.

Coura JR, Fernandes O, Arboleda MN, Barret TV, Carrara N, Degrave W, Campbell DA 1996. Human infection by Trypanosoma rangeli in the Brazilian Amazon. Trans R Soc Trop Med Hyg 90: 278-279.

Coura JR, Junqueira ACV, Giordano CM, Funatsu IRK 1994b. Chagas disease in the Brazilian Amazon. I - A short review. Rev Inst Med Trop São Paulo 36: 363-368.

Deane LM 1964. Animal reservoirs of Trypanosoma cruzi in Brazil. Rev Bras Malar 16: 27-48.

Fearnside MP 1982. Desmatamento na Amazônia brasileira: com que intensidade vem ocorrendo(?). Acta Amaz (Manaus) 12: 579-590.

Fernandes O, Souto RP, Castro JA, Pereira JB, Fernandes NC, Junqueira ACV, Naiff RD, Barret TB, Degrave W, Zingales B, Campbell DA, Coura JR 1998a. Brazilian isolates of Trypanosoma cruzi from humans and triatomines classified into two lineages using mini-exon and ribosomal RNA sequences. Am J Trop 
Med Hyg 58: 807-811.

Fernandes O, Sturm NR, Derre R, Campbell DA 1998b. The mini-exon gene: a molecular marker for zymodeme III of Trypanosoma cruzi. Mol Biochem Parasitol 95: 129-133.

Ferraroni JJ, Mello JAN, Camargo ME 1977. Moléstia de Chagas na Amazônia. Ocorrência de seis casos suspeitos, autóctones, sorologicamente positivos. Acta Amaz (Manaus) 7: 438-440.

Fife Jr EH, Muschel LH 1959. Fluorescent antibody technic for serodiagnosis of Trypanosoma cruzi infection. Proc Soc Exp Biol (NY) 101: 540-543.

Forattini OP 1980. Biogeografia, origem e distribuição da domiciliação de triatomíneos no Brasil. Rev Saúde Públ 14: 265-299.

Lent H, Wygodzinsky P 1979. Revision of the triatominae (Hemiptera, Reduviidae) and their significance as vectors of Chagas disease. Bull Amer Museum Nat History 163: 125-520.

Mascarenhas BM 1991. Triatomíneos da Amazônia: sobre o habitat e algumas considerações comportamentais de Rhodnius brethesi Matta, 1919 (Hemiptera, Reduviidae: Triatominae) na Região do Médio Rio Negro, Amazonas. Bol Mus Para Emilio Goeldi Serv Zool 7: 107-116.

Matta A 1919. Um novo reduvídeo do Amazonas. Rhodnius brethesi n.sp. Amazonas Med (Manaus) 2: 93-94.

Matta A 1922. Sobre o gênero Rhodnius do Amazonas.
Amazonas Med (Manaus) 5: 161-162.

Miles MA, Lanham SM, Souza AA, Povoa M 1980. Further enzymic character of Trypanosoma cruzi and their evaluation for strain identification. Trans $R$ Soc Trop Med Hyg 74: 221-237.

Miles MA, Souza AA, Povoa M 1981. Chagas disease in the Amazon Basin. III - Ecotopes of ten triatomine bug species (Hemiptera, Reduviidae) from the vinicity of Belém, Pará State, Brazil. J Med Ent 18: 266-278.

Miles MA, Arias JR, Souza AA 1983. Chagas disease in the Amazon Basin. V - Periurban palms as habitats of Rhodnius robustus and Rhodnius pictipes, triatominae vectors of Chagas disease. Mem Inst Oswaldo Cruz 78: 391-398.

Petana WB, Willcox HP 1975. New data on the comparative serology for Chagas disease, p. 292-294. In New Approaches in American Trypanosomiasis Research, PAHO, Washington.

Souza Lima MZM, Miranda Santos IKF, Souza AA, Naiff RD, Czeco YMT, Miles MA 1985. Caso humano de infecção mista por Trypanosoma cruzi e organismos tipo Trypanosoma rangeli procedente de Barcelos, Rio Negro, Amazonas, p. 44. In Programa e Resumos do XXI Congresso da Sociedade Brasileira de Medicina Tropical, São Paulo.

Valente SAA, Valente VC 1993. Situação da doença de Chagas na Amazônia. Rev Soc Bras Med Trop 26 (Suppl. 29): 68-70. 